\title{
GENERATION $Z$ AWARENESS ON FOOD WASTE ISSUES (A STUDY IN TANGERANG, INDONESIA)
}

\author{
Diena Mutiara Lemy, Audrey Rahardja and Cynthia Swastika Kilya \\ Universitas Pelita Harapan, Indonesia \\ diena.lemy@uph.edu
}

\begin{abstract}
With resources becoming scarcer, waste of food is something to be avoided. Food waste must be minimized by using various ways to avoid waste in terms of food loss and food waste. Food and beverage industry as part of hospitality industry also have important part in the food waste issue, where consumer behaviour has been one of the factor. This study will explore Generation Z's awareness of food waste problems in Indonesia, especially in the Tangerang and surrounding areas. The Generation $Z$ was chosen as the subject of the research because The availability of food in the future is one of the important issues for future generations, one of which is Generation $Z$. This research is exploratory in nature. The method is used to research something (which attracts attention) that is not yet known, not understood, or not well recognized. The data is collected using questionnaire that were distributed to respondents, namely Generation $Z$ in Tangerang and its surrounding areas. From the results of data processing and tests carried out in this study, it can be concluded that many of the Generation Z in Tangerang area Indonesia already have awareness about the food waste issue. However, it does not mean that there are no more problems to be followed up anymore. The awareness of food waste issue is still need to be increased because there were still 84 other respondents, with a percentage of $45.90 \%$, were not aware of the ongoing food waste issue.
\end{abstract}

Keywords: Food Waste; Food And Beverage Industry; Generation Z

\section{INTRODUCTION}

Currently, humans live in an era where the level of environmental damage is alarming. Human population is keep on increasing and growing rapidly, it is necessary to realize that the resources they have are decreasing. Whether it is certain animals and plants that are experiencing extinction, fishing is decreasing, the supply of clean water is decreasing, or so on, including reduced food sources. With resources becoming scarcer, waste of food is something to be avoided. Food waste must be minimized by using various ways to avoid waste in terms of food loss and food waste.

Gustavsson, Cederberg, \& Sonesson (2011) stated that problems that related to food waste has been raised and many policy and academic debates were focusing in this topic. It becomes very interesting because it has impacting the environmental, social and economic aspects. 
Okazaki, Turn, \& Flachsbart (2008) stated that the definition of food wastage is "any by-product or waste product from the production, processing, distribution, and consumption of food". This definition is similar with FAO - Food and Agriculture Organization of the United Nations (2013), saying that food loss was mainly caused by malfunctioning of the food production and supply system, both during the stages of planting, harvesting, processing, preserving and transforming agriculture. This can be due to managerial and technical limitations, such as a lack of proper storage facilities, cold chains, proper food handling practices, infrastructure, packaging, or an efficient marketing system. Meanwhile, leftover food itself refers to the elimination of the food supply chain that can still be consumed by humans. This can happen on purpose (by choice) or after food has been damaged or expired due to poor or neglected stock management. Loss of food that occurs at the end of the food chain is called "food waste", which is associated with the behavior of sellers and / or consumers.

The food and beverage industry as part of hospitality industry also have important part in the food wastage issues. Causes of food wastage in food and beverage industry were various. A study by Parfitt, Eatherley, Hawkins, \& Prowse (2013) stated that the daily average of food wastage before the cooking process is $95.4 \mathrm{~kg}$ which is caused by various reasons ranging from hygiene, wrong standards and inappropriate sizes. The food wastage also caused by the customer behaviour. Stenmarck et al., (2016) said that the minute the food arrives in front of customers, any food served and not consumed by patrons is branded as plate waste. This statement was confirmed by Kuo \& Shih (2016) whose study conclude that majority of plate waste is edible food due to poor quality, personal preferences, and over ordering.

In Indonesia itself, without realizing it, the issue of leftover food becomes very big. According to the Head of Representative of the United Nations Food Agency (FAO), Mark Smulders, of the approximately 1.3 trillion tons of food that was lost or wasted, Indonesia contributed around 13 million tons of food waste food loss and food waste (Detik.com, 2016). Furthermore, as quoted from data by the Economist Intelligence Unit (EIU) in 2016, Indonesia is in the second position of producing the most food waste in the world after Saudi Arabia. The following table shows that Indonesia is the second largest producer of food waste in the world.

Table 1: The Largest Producer of Food Waste in the World (per person per year)

\begin{tabular}{clc}
\hline No. & Country & Weight $(\mathrm{kg})$ \\
\hline 1. & Saudi Arabia & 427 \\
2. & Indonesia & 300 \\
3. & Amerika Serikat & 277 \\
4. & Uni Emirat Arab & 196 \\
\hline
\end{tabular}

Source: Economist Intelligence Unit (EIU), 2016 
In relation with the food waste that is caused by the behaviour of the customer, this research is interested to study the behaviour of Generation Z. The availability of food in the future is one of the important issues for future generations, one of which is Generation Z. This generation is born in the year 1996-2010 and now this generation has brought new worldview and different expectations as customers, employees, and citizens (Gaidhani, Arora, \& Sharma, 2019). Generation Z is the current productive generation who will become the successor and who will live and experience various environmental issues. One characteristic of Generation $\mathrm{Z}$ is that the Gen $Z$ are very much concerned with environmental issues, very conscious of looming shortages and water shortages which indicates that they have a high sense of responsibility towards the natural resources (Mihelich, 2013).

From the description above, this study will explore Generation Z's awareness of leftover food in Indonesia, especially in the Tangerang and surrounding areas. The population of Generation $\mathrm{Z}$ in the Tangerang and surrounding areas is estimated to be 514,968 people (Badan Pusat Statistik Republik Indonesia, 2018). To find out the knowledge of Generation $\mathrm{Z}$ in the Tangerang area and its surroundings regarding the issue of leftover food, researchers conducted a pre-survey. According to the pre-survey that has been conducted, there are 75 responses with the respondent profile as follows.

Table 2: Pre-survey Respondents' Profile

\begin{tabular}{cccc}
\hline No. & Age & Number & Percentage (\%) \\
\hline 1. & $16-18$ & 31 & 41,3 \\
2. & $19-21$ & 30 & 40 \\
3. & $22-24$ & 14 & 18,7 \\
\hline
\end{tabular}

The result of the pre-survey were as follows:

Table 3: Pre-Survey Results

\begin{tabular}{cccc}
\hline No. & $\begin{array}{c}\text { Are you aware of the } \\
\text { issue on food wastage? }\end{array}$ & Number & $\begin{array}{c}\text { Percentage } \\
(\%)\end{array}$ \\
\hline 1. & Yes & 31 & 41,3 \\
2. & No & 44 & 58,7 \\
\hline
\end{tabular}

Based on Table 3, most of the respondents who took part in the pre-survey answered that they did not know the current issue of leftover food $(58.7 \%)$. While the rest answered that they already knew the issue (41.3\%).

The purpose of this study is to get an overview of the awareness of issue of food wastage of generation Z. This is important because Generation Z's level of awareness and concern for the problem of leftover food is really needed to address the food wasting behaviour, since now the world is facing a scarcity of food resources. The Generation $\mathrm{Z}$ that becomes the subject of this research are 
Indonesian lin the Tangerang area and its surroundings, which includes, among others, the Gading Serpong area, Karawaci, and BSD.

\section{METHODOLOGY}

This research is exploratory in nature. The method is used to research something (which attracts attention) that is not yet known, not understood, or not well recognized. The date is collected using questionnaire that were distributed to respondents, namely Generation $\mathrm{Z}$ in Tangerang and its surrounding areas.

A non probability sampling was applied, and from 200 questionnaires that were being distributed, finally 183 were considered valid. The questionnaires were distributed by: e-mail and whatsapp through friends connections. It also printed in hardcopy and given straightly to the respondents in some locations (restaurants and malls in Tangerang area).

The respondents profile were as follows:

Table 4: Profile of Respondents

\begin{tabular}{|c|c|c|c|c|}
\hline No. & Question & Profile & $\begin{array}{c}\text { Frequenc } \\
\mathrm{y}\end{array}$ & $\begin{array}{c}\text { Percentage } \\
(\%)\end{array}$ \\
\hline \multirow{2}{*}{1.} & \multirow{2}{*}{ Gender } & Male & 81 & 44,26 \\
\hline & & Female & 102 & 55,74 \\
\hline \multirow{3}{*}{2.} & \multirow{3}{*}{ Age } & $16-18$ & 32 & 17,49 \\
\hline & & $19-21$ & 122 & 66,67 \\
\hline & & $22-24$ & 29 & 15,85 \\
\hline \multirow{5}{*}{3.} & \multirow{5}{*}{ Education } & Junior High School & 13 & 7,10 \\
\hline & & Senior High School & 152 & 83,06 \\
\hline & & Bachelor of Applied Science & 6 & 3,28 \\
\hline & & $\begin{array}{c}\text { Diploma 1/ Diploma 2/ } \\
\text { Diploma } 3\end{array}$ & 5 & 2,73 \\
\hline & & Others & 7 & 3,83 \\
\hline \multirow{6}{*}{4.} & \multirow{6}{*}{ Occupation } & High School Student & 16 & 8,74 \\
\hline & & University/College Student & 145 & 79,23 \\
\hline & & Workers & 10 & 5,46 \\
\hline & & Entrepreneurs & 9 & 4,92 \\
\hline & & Unemployed & 3 & 1,64 \\
\hline & & Others & 0 & 0,00 \\
\hline
\end{tabular}


The questionnaire used in this study was designed to get the perception of Generation $\mathrm{Z}$ about the food leftovers.

The list of questions were as follows:

\section{Table 4: List of Questions}

\begin{tabular}{ll}
\hline \multicolumn{1}{c}{ Questions } & Adapted from: \\
\hline Perceptions of food leftovers: & Waste Not, Want \\
1. In general, how much food is wasted when you & Not: A Case \\
eat? & Study on Food \\
$\square$ Many & Waste $\quad$ Restaurants of \\
$\square$ A reasonable amount & Lahore,Pakistan \\
$\square$ Very little & by M. Aamir, H. \\
$\square$ None & Ahmad, Javaid, dan S. \\
2. What do you usually do with leftovers? & 2018 Hasan. \\
$\square$ Throw it away & \\
$\square$ Wrap it up and take it home & \\
$\square$ Give it to my pet & \\
$\square$ Others &
\end{tabular}

3. When you wrap up leftovers, what's the main reason you do it?

I I don't have to cook again at home

- The food is delicious

I I want to share it with others

- I don't want to waste food

- I don't want to waste money

口 Others....

4. When you don't pack leftovers, what's the main reason you do it?

- I always finish my food

I I am embarrased to wrap food and bring it home

$\square$ The leftover is so little and not worth to be wrapped up

I I will waste it anyway

I I don't want to be critized

$\square$ Others....

5. Why do you think it is important not to waste 


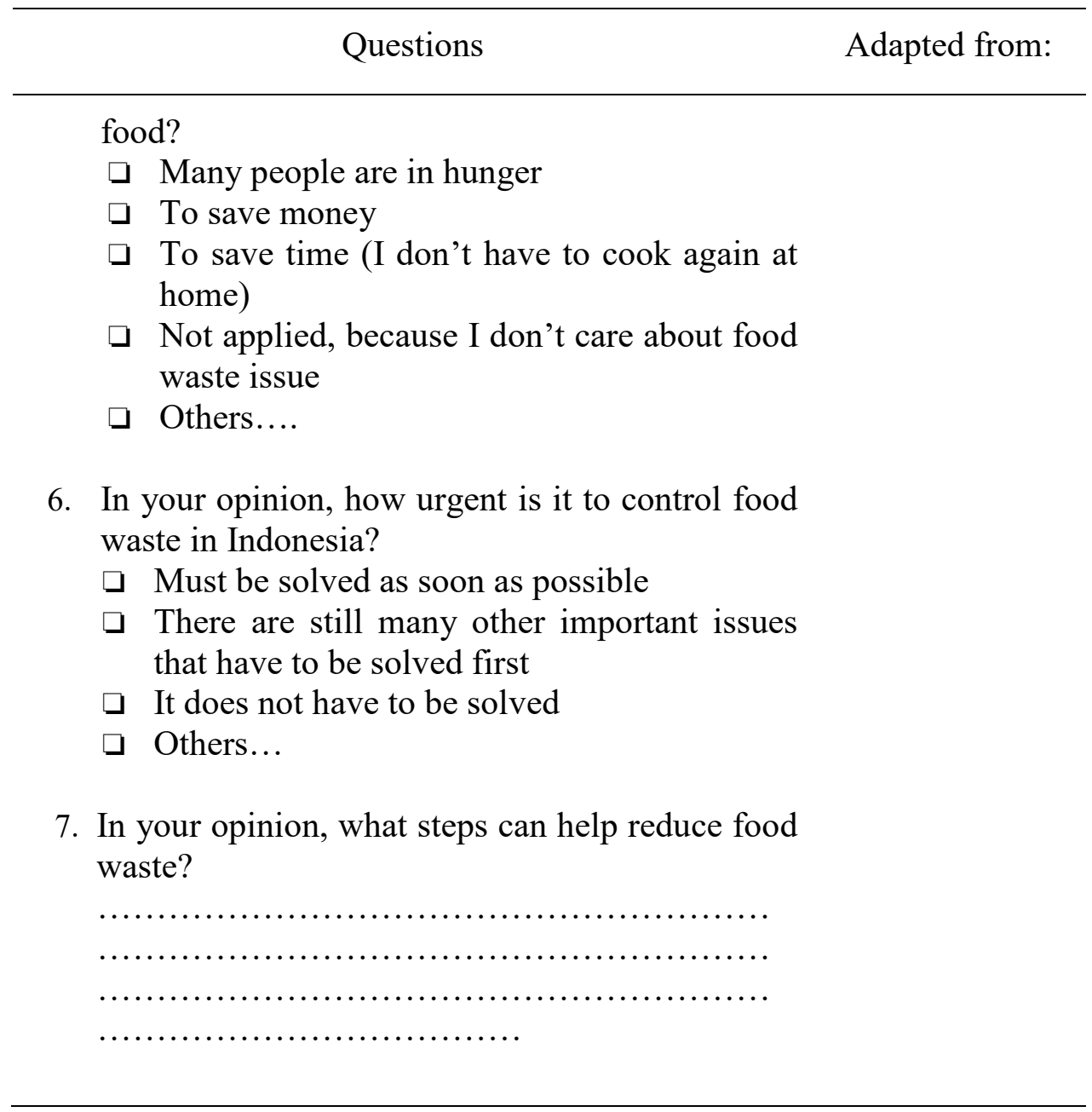

\section{RESULTS AND DISCUSSION}

This study explore the Generation $\mathrm{Z}$ awareness on food waste issues.

From 183 respondents, the response for question of 'In general, how much food is wasted when you eat? There were eight respondents $(4.40 \%)$ who threw away food in large quantities, 55 respondents $(30.10 \%)$ who threw away food in a reasonable amount, 78 respondents $(42.60 \%)$ who threw away food in very small amounts and 42 respondents $(23 \%)$ did not waste their food at all.

The next question were 'What do you usually do with leftovers?'the response were: 55 respondents $(30.10 \%)$ throw it away, 62 respondents $(33.90 \%)$ wrap it and take it home, 50 respondents $(27.30 \%)$ give it to their pets, and 66 respondents $(36,07 \%)$ answer the option "Other". The "Other" option includes eight answers that they try to consume the entire meal slowly, seven answers share it with people who eat together with them and one answer does all the activities in that choice.

For the question of 'When you wrap up leftovers, what's the main reason you do it?' the respondents said that they wrap the food because they did not have to cook food again at home were 36 people $(19.70 \%), 12$ people $(6.60 \%)$ wrap it because the food is delicious, 25 people $(13.70 \%)$ wanted to share it with other people (13.70\%) and didn't want to waste it. 88 people (48.10\%) did not waste food, 18 people did not want to waste money $(9.80 \%)$, and four people answered "Other" (2.20\%). The "Other" option includes three answers because they are too full and 
could not finish it right away and one answer because they want to be given to their pets.

Meanwhile, when the respondent did not wrap food, respondents who chose the reason because usually the respondents always finish their food were 92 people (50.27\%), too embarrassed to wrap food and bring it home 17 people $(9.29 \%)$, the leftover food was not enough to be wrapped up 39 people $(21.31 \%), 23$ people $(12.57 \%)$ usually waste their food, 8 people did not want to be criticized by friends $(4.37 \%)$, and four people choose other options $(2.19 \%)$. The "Other" option includes two answers because the food ordered is not good, one answer because they don't want to finish the food, and one answer that has no reason.

The next question were 'Why do you think it is important not to waste food?', the response were as follows: 140 answers $(53 \%)$ of people who choose not to waste food because many people are in hunger, 81 answers (30.70\%) were to save money, to save (because they don't have to cook again at home) as much as 24 answers $(9.10 \%)$, and respondents who do not care about food waste as many as 14 answers $(5.30 \%)$, and those who answered "Other" were five answers (1.90\%). The "Other" option includes reasons that it is wasteful to leave the food.

For the sixth question, 'In your opinion, how urgent is it to control food waste in Indonesia?' the respondents responded as follows: Issues related to food waste must be resolved as soon as possible as many as 101 people $(55.20 \%)$, respondents who answered other issues must be resolved first as many as 71 people $(38.80 \%)$, respondents who answered that they did not need to be resolved were 11 people $(6 \%)$, and no there are respondents who answered the choice "Other" $(0.00 \%)$.

The last question were an open question. The question was: 'In your opinion, what steps can help reduce food waste?' Some of the steps written by respondents were: First, Reminding others not to over-order food; second, remind others to finish the food that has been purchased; third, application of additional prices in restaurants for the remaining food; restaurants can add portion sizes such as one, half or half portions in their menu; fourth, educating Generation $\mathrm{Z}$ on the issue of food waste; fifth, use of social media to disseminate appeals on the issue of food waste; seventh, supermarkets provide recommendations in the form of an appeal to purchase food products in large quantities.

\section{DISCUSSION}

Based on the results of the questionnaires that have been distributed, the responses had shown a sign that half of the repondents had shown awareness towards food waste issues. Most of the respondents always try not to waste their food by try to finish it up, wrap it and give to others (people or their pets). They also know that many people in the world are in hunger so it is not good to waste food. and Generation $Z$ the number of Generation $Z$ who have awareness of the problem of food waste by minimizing leftover food is 99 respondents $(54.10 \%)$ from a total of 183 valid respondents. The awareness of food waste can be seen from the result that almost half of the respondents try not to waste their food. Meanwhile, 84 other respondents, with a percentage of $45.90 \%$, were not aware of the ongoing food waste issue. Of the 84 respondents who were not aware of the issue of food waste, there were 55 respondents $(30.10 \%)$ who preferred to dispose of leftover food rather than storing or giving it to others. This is in accordance with the theory put forward by the Generational White Paper (2011) where it is stated 
that Generation $\mathrm{Z}$ has the characteristics of a tendency to be impatient and has an instant way of thinking.

The main reason that Generation $\mathrm{Z}$ chose not to throw away leftover food was that they did not want to waste food ( 88 respondents $(48.10 \%)$ ). This result can be proven by the majority of respondents saying that they always finish their food $(50.27 \%)$. There is a parallel from previous research, in that the aforementioned results suggest that there is a strong 'bad feel' factor when respondents waste food, which provides a good basis for food waste prevention efforts.

According to 140 respondents $(53.03 \%)$, it is important not to waste food because they think there are still many hungry people out there. As well as 101 respondents $(55.19 \%)$ also said that the issue of food waste must be resolved as soon as possible. This is evidenced by the theory of Mihelich (2013) mentioned earlier, which states that Generation $Z$ has a high level of concern for the environment around it.

\section{CONCLUSION}

From the results of data processing and tests carried out in this study, it can be concluded that many of the Generation $\mathrm{Z}$ in Tangerang area Indonesia already have awareness about the food waste issue. However, it does not mean that there are no more problems to be followed up anymore. The awareness of food waste issue is still need to be increased because there were still 84 other respondents, with a percentage of $45.90 \%$, were not aware of the ongoing food waste issue. Of the 84 respondents who were not aware of the issue of food waste, there were 55 respondents $(30.10 \%)$ who preferred to dispose of leftover food rather than storing or giving it to others. Because if it is not improved, of course it will not produce the desired results, namely environmental preservation for a better future for the survival of the earth and its people. It will also help in sustainable tourism, because abundant resources are one of the factors that can support tourism itself. Meanwhile, as is well known, the resources that are owned are now running low.

Increasing Generation Z's awareness of food waste will avoid the food and beverage industry to contribute to food waste problems that comes from the consumer behaviour. They can make programs and strategy to raise Generation Z's awareness of the problem of leftover food. There are several examples such as reminding consumers not to over-order food by informing the portions of each food, implementing price increases for food that is not finished, reminding others not to waste food by social media campaign, and so on. Therefore, the issue of food waste must be resolved as soon as possible to support life of the next generation, including Generation Z.

This research have some limitations. First, it is only exploring the cause of food waste from the consumer behavior side. Second, the respondents were only comes from Tangerang area. Third, the sampling method were using non probability sampling. For the next research, an exploration on the larger population of Generation $\mathrm{Z}$ will add more insights on this issue. In addition, the other factors affecting food waste issues is also suggested.

\section{REFERENCES}

Badan Pusat Statistik Republik Indonesia. (2018). Penduduk menurut Kelompok Umur dan Jenis Kelamin di Kota Tangerang. Retrieved 12 December 2020, 
from https://tangerangkota.bps.go.id/dynamictable/2015/11/27/21/pendudukmenurut-kelompok-umur-dan-jenis-kelamin-di-kota-tangerang-2018.html

Detik.com. (2016). 13 Juta Ton Makanan Terbuang Percuma di RI Setiap Tahun. Retrieved 12 December 2020, from https://finance.detik.com/wawancarakhusus/d-3317570/13-juta-ton-makanan-terbuang-percuma-di-ri-setiap-tahun

Food and Agriculture Organization of the United Nations. (2013). Food Wastage Footprint: Impacts on Natural Resources. Roma: Secretariat HLPE c/o FAO.

Gaidhani, S., Arora, L., \& Sharma, B. K. (2019). Understanding the attitude of generation $\mathrm{Z}$ towards workplace. International Journal of Management, Technology And Engineering, 9(1), 2804-2812.

Generational White Paper. (2011). Generation Z and the Career Strategist. Retrieved 12 December 2020, from http://www.workcomms.com/graduates/whitepapers/Generation-Z/.

Gustavsson, A., Cederberg, C., \& Sonesson, U. (2011). Global Food Losses and Food Waste: Extent, Causes and Prevention. Food and Agriculture Organization of the United Nations (FAO). Düsseldorf: SIK -The Swedish Institute for Food and Biotechnology.

Kuo, C., \& Shih, Y. (2016). Gender differences in the effects of education and coercion on reducing buffet plate waste. Journal of Foodservice Business Research, 19(3), 223-235.

Mihelich, M. (2013). Another generation rises. Workforce Management, 92(5), 34 38. Retrieved from http://www.workforce.com/section/magazine

Okazaki, W. K., Turn, S. Q., \& Flachsbart, P. G. (2008). Characterization of food waste generators: A Hawaii case study. Waste Management, 28(12), 24832494. https://doi.org/https://doi.org/10.1016/j.wasman.2008.01.016

Parfitt, J., Eatherley, D., Hawkins, R., \& Prowse, G. (2013). Overview of waste in the UK hospitality and food service sector. United Kingdom: Banbury.

Stenmarck, Å., Jensen, C., Quested, T., Moates, G., Buksti, M., Cseh, B., ... Östergren, K. (2016). Estimates of European food waste levels. Sweden: IVL Swedish Environmental Research Institute. 